29. Schwartz R, Momburg F, Moldenhauer G, Dörken B, Schirrmacher $V$. Induction of HLA class-II antigen expression on human carcinoma cell lines by INF-gamma. Int $\mathcal{F}$ Cancer 1985, 35, 245-250.

30. Klareskog L, Forsum U, Peterson PA. Hormonal regulation of the expression of Ia antigens on mammary gland epithelium. Eur $\mathcal{F}$ Immunol 1980, 10, 958-963.

31. Bernard DJ, Maurizis JC, Chassagne J, Chollet P, Plagne R. Effect of prolactin on class-II HLA antigens expression by MCF-7 cell line. Anticancer Res $1980,6,79-84$.

32. Shafie S, Brooks SC. Effect of prolactin on growth and the estrogen receptor level of human breast cancer cells (MCF-7). Cancer Res $1977,37,792-799$

33. Dhadly MS, Walker RA. The localization of prolactin binding sites in human breast tissue. Int $\mathcal{F}$ Cancer 1983, 31, 433-437.

34. Kleinberg DL. Prolactin and breast cancer. $N$ Engl f Med 1987, 316, 269-270.

35. Wallich R, Bulbuc N, Hämmerling GJ, Katzau S, Segal S, Feldman $M$. Abrogation of metastatic properties of tumor cells by de novo expression of $\mathrm{H}-2 \mathrm{~K}$ antigens following $\mathrm{H}-2$ gene transfection. Nature 1985, 315, 301-306.

36. Birkby CA, Curtis ASG, McGrath M, Ripley BD. MHC control of cell position in vitro. 7 Cell Sci 1988, 89, 167-174.

37. Hirayama K, Matsushita S, Kikuchi I, Iuchi M, Ohta N, Sasazuki
T. HLA-DQ is epistatic to IILA-DR in controlling the immunc response to schistosomal antigen in humans. Nature 1987, 327 , $426-430$.

38. Baxevanis $\mathrm{CN}$, Ishii $\mathrm{N}$, Nagy ZA, Klein J. H-2 controlled sup pression of T-cell response to lactate dehydrogenase B. $\mathcal{F}$ Exp Med $1982,156,822-833$.

39. Matis LA, Jones PP, Murphy DB, et al. Immune response gene function correlates with the expression of an Ia antigen. II. Quantitative deficiency in Ae:Ea complex expression causes a corresponding defect in antigen-presenting cell function. $\mathcal{J}$ Exp Med 1982 $155,503-523$

40. Diedrichs $M$, Schendel DJ. Differential surface expression of class II molecules on activated CD4 and CD8 cells correlates with levels of locus-specific messenger RNA. F Immunol 1989, 142, 3275-3280.

41. Ombra MN, Del Pozzo G, Perfetto C, Maffei A, Guardiola J. Effect of the AIR-1 locus on the activation of an enhancerless HLA-DQA1 promoter. Immunogenetics $1990,31,368-376$.

Acknowledgements-This work was supported by a grant from the Deutsche Forschungsgemeinschaft, SFB 217 (A3).

We thank Dr J. Baltzer for tissue specimens and Dr A. Ziegler and Dr F. Bach for providing monoclonal antibodies. We also thank Dr W. Eiermann and Dr E. Kuß for providing hormone receptor analysis.

\title{
Inhibition of the Growth of Cultured Human Meningioma Cells by Recombinant Interferon- $\alpha$
}

\author{
Jan W. Koper, Ellen C. Zwarthoff, Anne Hagemeijer, Reinder Braakman, \\ Cees J.J. Avezaat, Mats Bergström and Steven W.J. Lamberts
}

In this paper the results of investigations on the effect of interferon- $\alpha$ (IFN- $\alpha$ ) on the growth of meningioma cells in culture is reported. A consecutive series of six meningiomas and one meningioma/neurofibroma derived from a patient with neurofibromatosis type 2 was investigated and it was found that the growth of all seven tumours in response to mitotic stimuli (fetal bovine serum or epidermal growth factor) is strongly inhibited by IFN- $\alpha$. Maximal response varied between $100 \%$ and $70 \%$ inhibition of the incorporation of tritiated thymidine. In some cases an inhibitory response was obtained already at very low doses ( $\leq 10 \mathrm{U}$ of IFN- $\alpha$ per ml). These results indicate that further clinical investigation of the application of IFN- $\alpha$ to the treatment of meningioma is warranted. Eur F Cancer, Vol. 27, No. 4, pp. 416-419, 1991

\section{INTRODUCTION}

MENINGIOMAS, tumours arising from the arachnoidial cell-layer surrounding the brain [1] are usually slowly growing, benign tumours. There are strong indications that the cause of meningiomas is the inactivation or loss of both copies of a putative tumour suppressor gene located on the long arm of chromosome $22[2,3]$. This aetiology is probably shared with one of the inheritable forms of neurofibromatosis (bilateral acoustic neuro-

Correspondence to J.W. Koper.

J.W. Koper and S.W.J. Lamberts are at the Department of Medicine, Room Bd 281; E.C. Zwarthoff is at the Department of Pathology; A. Hagemeijer is at the Department of Genetics and R. Braakman and C.J.J. Avezaat are at the Department of Neurosurgery, Erasmus University Rotterdam, P.O. Box 1738, 3000 DR Rotterdam, The Netherlands; and $M$. Bergström is at the Department of Neurology, Uppsala University Hospital, Uppsala, Sweden.

Revised 20 Dec. 1990; accepted 4 Jan. 1991. fibromatosis or neurofibromatosis type 2) [3, 4] and possibly with some glial tumours [3].

The common treatment for meningiomas is surgical removal; however, the recurrence rate is considerable [5] and not all meningiomas are easily accessible to surgery. For these reasons other possibilities for treatment are investigated. The presence of receptors for progesterone in many meningioma tissues [6] has led to a number of research papers dealing with the possibilities of therapy using antiprogestins such as mifepristone [7-9].

Similarly, the discovery of the presence of high concentrations of specific receptors for somatostatin in meningioma membranes [10] has resulted in a number of reports about the effects of somatostatin (analogues) on the growth of meningiomas or cultured meningioma cells [11-13]. Contrary to one report in the literature [11], we have not been able to show inhibitory effects of somatostatin (analogues) on the growth of meningiomas (refs 12 and 13, and J.W.K. et al.). 
Interferons (IFNs) are a group of proteins that were first recognised by their ability to protect the cell against viral infections (see ref. 14 for review). The ability of IFNs to influence cell-proliferation and differentiation has only become apparent during the last two decades $[15,16]$. Since then it has become clear that the IFNs can be of clinical use in treatment of a number of haematological and solid tumours [17].

We have previously reported preliminary results of the treatment of meningioma patients with interferon- $\alpha$ (IFN- $\alpha$ ) [13] Here we report the results of experiments on the response of cultured human meningioma cells to recombinant human IFN$\alpha$. In addition to this we investigated the response to IFN- $\alpha$ of cells derived from a meningioma/neurofibroma removed from a patient with neurofibromatosis type 2 . The data presented here show that the mitogen-stimulated growth of meningioma cells in vitro and of the meningioma/neurofibroma cells can be reduced significantly by IFN- $\alpha$ in concentrations below $1000 \mathrm{U} / \mathrm{ml}$.

\section{MATERIALS AND METHODS}

\section{Meningioma tissues and cell culture}

Tumour specimens were obtained within $30 \mathrm{~min}$ after surgery They were brought into culture as described previously [9]. After two or three weeks, when the cells had grown to confluency, and dead cells, blood cells and debris resulting from the isolation procedure had been washed away by the medium changes, the cells were harvested as described [9]. The cells were collected by centrifugation, washed, suspended in fresh culture medium and seeded into 24-well tissue culture plates (Costar Europe, Badhoevedorp, The Netherlands) at $4 \times 10^{4}$ cells/well in $1 \mathrm{ml}$ of medium.

\section{Cytogenetic analysis of cultured cells}

Colcemid $(75-\mathrm{ng} / \mathrm{ml})$ was added to early passages $(0-3)$ of meningioma monolayer cell cultures in logarithmic growth. After $6 \mathrm{~h}$ the mitotic cells were detached into the supernatant by vigorous shaking. The supernatants were collected into tubes and centrifuged. The mitotic cells were processed further according to standard cytogenetic procedures [18]. The remain ing monolayer in the culture flasks was flooded with KCl-EGTA [19] for $20 \mathrm{~min}$, scraped off with a rubber policeman, washed with $75 \mathrm{mmol} / 1 \mathrm{KCl}$ and processed as above. The chromosomes were identified using R-, Q- and G-banding techniques and analysed according to the International System for Chromosome Nomenclature [20].

\section{Mitogen-stimulated incorporation of tritiated thymidine}

When the cells in 24-well-plates had grown to conflucncy, the culture medium was removed and replaced by serum-free medium as described previously [9]. The cells were maintained in this medium for 3 days, after which the medium was replaced by fresh serum-free medium, and the experiment was started by addition of epidermal growth factor (EGF, $10 \mathrm{ng} / \mathrm{ml}$ ) or fetal bovine serum (FBS, 10\%) and IFN- $\alpha(0,10,100$ or 1000 $\mathrm{U} / \mathrm{ml}$ ). All incubations were carried out in triplicate. $20 \mathrm{~h}$ later, $3.7 \times 10^{4} \mathrm{~Bq}$ of [methyl ${ }^{3} \mathrm{H}$ ] thymidine was added to each well $\left(2.2-3.3 \times 10^{12} \mathrm{~Bq} \mathrm{mmol}\right.$, Amersham Nederland, Houten, The Netherlands). The cells were then incubated for $4 \mathrm{~h}$, the medium was removed, the cells were washed twicc with cold $0.15 \mathrm{~mol} /$ $\mathrm{NaCl}$, solubilised with $1 \mathrm{~mol} / \mathrm{l} \mathrm{NaOH}$ and transferred to vials for scintillation counting of the incorporated radioactivity.

\section{Mitogen-stimulated growth}

Cells were grown to semi-confluency in Dulbecco's modified Eagle's medium (DMEM) with 10\% FBS in 24-well tissue
Table 1. Histological and cytogenetic analysis of the meningiomas

\begin{tabular}{lccll}
\hline Case & M/F & Age & \multicolumn{1}{c}{ Histology } & Karyotype \\
\hline 1 & $M$ & 65 & Syncitial and transitional & $46, \mathrm{XY}$ \\
2 & $\mathrm{M}$ & 42 & Meningiotheliomatous & $\mathbf{4 6 , \mathrm { XY }}$ \\
3 & $\mathrm{~F}$ & 74 & Psammomatous & $45, \mathrm{XX},-22$ \\
4 & $\mathrm{~F}$ & 60 & Psammomatous & $45, \mathrm{XX},-22$ \\
5 & $\mathrm{M}$ & 70 & Fibromatous & $\mathrm{ND}$ \\
6 & $\mathrm{~F}$ & 75 & Psammomatous and transitional & $45, \mathrm{XX},-22$ \\
7 & $\mathrm{~F}$ & 33 & $\begin{array}{c}\text { Meningioma/neurofibroma } \\
\text { (type 2 neurofibromatosis) }\end{array}$ & $44, \mathrm{X},-22$ \\
& & & \\
\hline
\end{tabular}

$\mathrm{ND}=$ not determined

culture plates. The medium was replaced by serum-free medium plus EGF $(10 \mathrm{ng} / \mathrm{ml})$ or by fresh DMEM/10\% FBS and IFN- $\alpha$ was added at concentrations of $0,10,100$ or $1000 \mathrm{U} / \mathrm{ml}$. The cells were then cultured under these conditions for 7 days, with daily replacement of the medium and all the factors added. At the end of the experiment, the cultures were washed once with $0.15 \mathrm{~mol} / 1 \mathrm{NaCl}$ and lysed in $125 \mu \mathrm{l} 1 \mathrm{~mol} / 1 \mathrm{NH}_{4} \mathrm{OH}, 0.2 \%$ "Triton-X-100". The lysates were sonicated ( $1 \mathrm{~s}$ in an MSE Soniprep 150 at half-maximal output) and diluted with $1 \mathrm{ml}$ $10 \mathrm{mmol}$ HEPES buffer with $100 \mathrm{mmol} / 1 \mathrm{NaCl}$ and $10 \mathrm{mmol} / \mathrm{l}$ EDTA ( $\mathrm{pH} \mathrm{7.0)}$. The DNA-content was then measured in the samples using the bisbenzimide fluorescent dye (Behring Diagnostics, La Jolla, USA) as described [21]

Materials

Human EGF (recombinant) was obtained from Boehringer Mannheim, Almere, The Netherlands. Human IFN- $\alpha$ (recombinant, Roferon ${ }^{\mathrm{TM}}$ ) was obtained from Hoffmann-La Roche, Basel, Switzerland.

\section{Statistics}

The statistical significance of the differences between mean values was determined using one-way analysis of variance (ANOVA). When significant overall effects were obtained by ANOVA, multiple comparisons were made using the Newman-Keuls test. All data are expressed as mean (S.D.) percentages, relative to the control values.

\section{RESULTS}

Table 1 gives the clinical and histological data of the tumour samples used in this study. As can be seen in the table several different histological types of meningioma were used.

Cytogenic analysis was performed on cultured tumour cells from 6 of the 7 cases. This analysis revealed that at least 4 of the 7 tumour samples ( 3 meningiomas and the meningioma/ neurofibroma) showed changes with regard to chromosome 22 that are characteristic of meningioma and neurofibromatosis type 2 (Table 1). In all cases these changes consisted of the loss of one entire copy of chromosome 22.2 cultured meningiomas had a normal karyotype upon examination. This may indicate that the changes in these meningiomas were too small for detection at cytogenetic level (e.g. minor deletions or point mutations). For one meningioma sample, insufficient material was available for cytogenetic analysis (case 5).

We tested the EGF-response of 5 of these meningiomas (cases $1,2,3,5$ and 6) and of the meningioma/neurofibroma (case 7) and examined the effect of IFN- $\alpha$ on this stimulation in a thymidine incorporation assay. The results of these experiments 
Table 2. Inhibition of EGF-stimulated $\left[{ }^{3} \mathrm{H}\right]$ thymidine incorporation in cultured meningioma cells by IFN- $\alpha$

\begin{tabular}{|c|c|c|c|c|c|}
\hline \multirow[b]{2}{*}{ Case } & \multirow[b]{2}{*}{ Control } & \multicolumn{4}{|c|}{ EGF } \\
\hline & & Alone & $\begin{array}{l}10 \mathrm{U} / \mathrm{ml} \\
\text { IFN- } \alpha\end{array}$ & $\begin{array}{c}100 \mathrm{U} / \mathrm{ml} \\
\mathrm{IFN}-\alpha\end{array}$ & $\begin{array}{c}1000 \mathrm{U} / \mathrm{ml} \\
\text { IFN- } \alpha\end{array}$ \\
\hline 1 & $100(7)$ & $321(10)^{\star}$ & $206(7)^{\star} \dagger$ & $144(4)^{\star} \dagger$ & $79(10) \dagger$ \\
\hline 2 & $100(14)$ & $232(11)^{\star}$ & $137(4)^{\star} \dagger$ & $85(5) \dagger$ & $53(4)^{\star} t$ \\
\hline 3 & $100(4)$ & $106(5)$ & $107(7)$ & $100(1)$ & $94(6)$ \\
\hline 5 & $100(6)$ & $150(12)^{\star}$ & $147(5)^{\star}$ & $114(7)$ & $93(7) \dagger$ \\
\hline 6 & $100(3)$ & $365(3)^{\star}$ & $255(8)^{\star} \dagger$ & $163(3)^{\star} \dagger$ & $82(19) \dagger$ \\
\hline 7 & $100(21)$ & $147(7)^{\star}$ & $92(4) \dagger$ & $78(2) \bullet \|$ & $69(3)^{\star}+$ \\
\hline
\end{tabular}

Means (S.D.) expressed as percentage of the unstimulated controls; $n=3$.

Significantly different from untreated controls: ${ }^{\star} P<0.01, \bullet P<0.05$; significantly different from stimulated controls: $\dagger P<0.01, \| P<0.05$.

(Table 2) show that 4 (cases 1, 2, 5 and 6) out of the 5 meningiomas tested and also the meningioma/neurofibroma (case 7) responded to EGF by an increased incorporation of tritiated thymidine. The response to EGF was rather variable and ranged from $50 \%$ to $265 \%$ increase in the incorporation of $\left[{ }^{3} \mathrm{H}\right]$ thymidine. In these 4 meningiomas and in the meningioma/neurofibroma IFN- $\alpha$ significantly inhibited the effect of EGF. In one meningioma (case 2) and in the meningioma/neurofibroma (case 7) IFN- $\alpha$ even reduced the thymidine incorporation to a level significantly below that observed in unstimulated control cells.

In view of the observed lack of response of one meningioma (case 3) to EGF we carried out a similar thymidine incorporation assay with this meningioma and three other meningiomas (cases 4, 5 and 6) and with the meningioma/neurofibroma (case 7), now using a less specific stimulant: FBS. Table 3 shows that all 4 meningiomas tested in this way and the meningioma/neurofibroma responded to FBS by an increased incorporation of $\left[{ }^{3} \mathrm{H}\right]$ thymidine. The response to $\mathrm{FBS}$ was rather more vigorous than that to EGF (cf. cases 5, 6 and 7). In all 5 cases this stimulation was significantly reduced by IFN- $\alpha$. In the meningioma (case 3) shown in Table 2 not to respond to EGF, IFN- $\alpha$ at $1000 \mathrm{U} / \mathrm{ml}$, after FBS stimulation, resulted in a reduction of thymidine incorporation to a level significantly below the level observed in unstimulated control cells (Table 3 ).

To assess whether IFN- $\alpha$ merely inhibited the stimulated

Table 3. Inhibition of FBS-stimulated $\left[{ }^{3} \mathrm{H}\right]$ thymidine incorporation in cultured meningioma cells by IFN- $\alpha$

\begin{tabular}{llllll}
\hline & & \multicolumn{5}{c}{ FBS } \\
\cline { 3 - 6 } Case & Control & Alone & $\begin{array}{c}10 \mathrm{U} / \mathrm{ml} \\
\text { IFN- } \alpha\end{array}$ & $\begin{array}{c}100 \mathrm{U} / \mathrm{ml} \\
\text { IFN- } \alpha\end{array}$ & $\begin{array}{c}1000 \mathrm{U} / \mathrm{ml} \\
\text { IFN- } \alpha\end{array}$ \\
\hline 3 & $100(2)$ & $199(5)^{\star}$ & $124(4)^{\star} \dagger$ & $93(4) \dagger$ & $68(8)^{\star} \dagger$ \\
4 & $100(9)$ & $503(10)^{\star}$ & $462(4)^{\star}$ & $379(5)^{\star} \dagger$ & $200(7)^{\star} \dagger$ \\
5 & $100(3)$ & $271(3)^{\star}$ & $268(13)^{\star}$ & $262(8)^{\star}$ & $204(5)^{\star} \|$ \\
6 & $100(10)$ & $653(1)^{\star}$ & $594(3)^{\star} \|$ & $489(9)^{\star} \dagger$ & $298(5)^{\star} \dagger$ \\
7 & $100(9)$ & $207(5)^{\star}$ & $161(15)^{\star} \dagger$ & $131(5)^{\bullet} \dagger$ & $81(1)^{\dagger} \dagger$ \\
\hline
\end{tabular}

Significantly different from untreated uncontrols: ${ }^{\star} P<0.01, \bullet P<0.05$; significantly different from stimulated controls: $+P<0.01, \| P<0.05$.
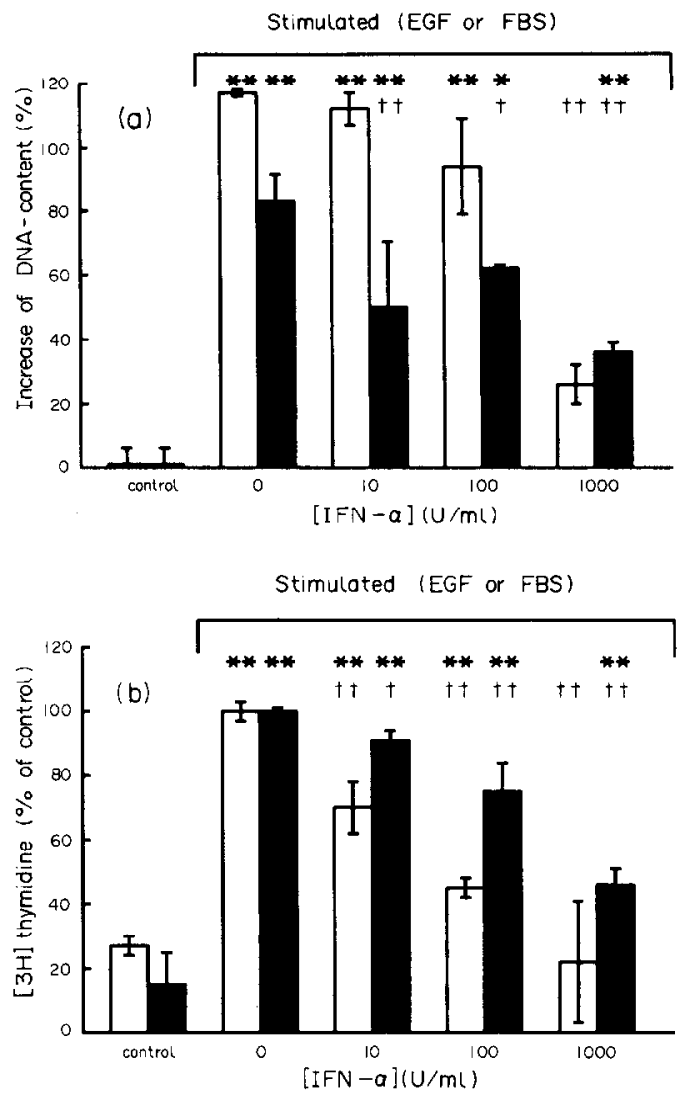

Fig. 1. The effect of IFN- $\alpha$ on the increase of DNA-content (upper) and $\left[{ }^{3} \mathrm{H}\right]$ thymidine-incorporation (lower) in human meningioma cellcultures. Cell cultures derived from meningioma 6 were stimulated with EGF ( $10 \mathrm{ng} / \mathrm{ml}$, open bars) or FBS (10\%, filled bars) in the presence of IFN- $\alpha$ as indicated. The increase of DNA-content is given as percentage increase (S.D.) $(n=3)$ relative to the DNA content of unstimulated control cultures (these contained $1.58 \pm 0.08 \mu \mathrm{g}$ DNA per well), thymidine incorporation as percentage (S.D.) relative to the stimulated controls. Incorporation by unstimulated cells is indicated by the bars on the left side. ${ }^{\star}$ and $\star \star$ : significantly different from untreated controls at $P<0.05$ and $P<0.01$, respectively; $\dagger$ and $H$ : significantly different from stimulated controls at $P<0.05$ and $P<0.01$, respectively.

incorporation of tritiated thymidine or really slowed the proliferation of cultured meningioma cells, we stimulated meningioma cultures (case 6) with either EGF or FBS and measured their DNA content after a week of treatment with IFN- $\alpha$. The results are presented in Fig. 1, together with the data on thymidine incorporation for the same meningioma. IFN- $\alpha$ significantly inhibited growth stimulation by EGF and FBS in this meningioma. The inhibition of FBS-stimulated growth by IFN- $\alpha$ was less than the inhibition of EGF-stimulated growth. As can be seen these results approximately paralleled those obtained in the thymidine-incorporation assay (Fig. 1).

\section{DISCUSSION}

The IFNs are a family of proteins first discovered (and named) by their interference with viral infections. Only during the last 20 years it has become clear that they can also influence growth and differentiation of (tumour) cells $[15,16]$. Work in vitro has shown that IFNs inhibit the growth of a remarkable variety of cells [15]. Even though the action of IFNs may be cytostatic rather than cytotoxic or cytocidal, this growth-inhibitory action makes them interesting subjects in research about the treatment 
of tumours. There are now a number of tumours that can be treated with good to reasonable success with IFNs [17].

We have observed an inhibitory effect of IFN- $\alpha$ on the metabolism of meningiomas in patients, using $\left[{ }^{11} \mathrm{C}\right]-\mathrm{L}$-methionine positron emission tomography [13]. In some of the patients IFN- $\alpha$ treatment resulted in a decreased growth-rate of their meningiomas.

We found that the growth of meningioma cells in culture was inhibited by IFN- $\alpha$. The cells were derived from 6 different meningiomas of various histological types. In addition to the meningiomas, we used cultured cells derived from a falx-located tumour removed from a patient with neurofibromatosis type 2 [22]. The patient had multiple central and spinal meningiomas, bilateral acoustic neurinomas and bilateral optic tumours. This tumour had histological characteristics both of a meningioma and of a neurofibroma and is, therefore, referred to as "meningioma/neurofibroma". In all these tumour cells the growth, stimulated by specific (EGF) or non-specific (FBS) mitogens, was reduced or abolished by exposure to IFN- $\alpha$. Interestingly, these inhibitory effects were observed at relatively low doses: significant reduction at $10 \mathrm{U} / \mathrm{ml} \mathrm{IFN-} \alpha$ in 3 of the 6 meningiomas tested and significant reduction at $100 \mathrm{U} / \mathrm{ml}$ IFN- $\alpha$ in all meningiomas. Moreover, in all meningiomas responsive to EGF, the stimulation of thymidine-incorporation by EGF could be abolished completely by $1000 \mathrm{U} / \mathrm{ml} \mathrm{IFN}-\alpha$. This is especially interesting in view of the observed presence of EGF-receptors in a large proportion of meningiomas [12]. Presumably the meningioma that could not be stimulated by EGF was EGFreceptor negative; however, we did not have sufficient material to confirm this. Similarly, differences in response may represent differences in receptor density.

The effects of interferon- $\alpha$ were similar after stimulation with EGF and FBS, both with respect to thymidine incorporation and increase in DNA-content. Since meningioma cells - certainly in early passages — can be propagated quite easily in FBS containing medium, this indicates that interferon- $\alpha$ actually inhibited cell proliferation rather than specific parts of this process.

The cytogenetic analysis showed that loss of one copy of chromosome 22 had occurred in 3 our of 5 meningiomas tested and also in the meningioma/neurofibroma cells from a patient suffering from neurofibromatosis type 2 . This gives additional support to the notion that these diseases have a common aetiology as suggested [2-4]. It also confirms that, certainly in the early stages of culture, the cultured meningioma cells used in this study were indeed meningioma cells and not stromal cells overgrowing the original tumour cells.

Cells derived from a different tumour (meningioma/neurofibroma) but with the same aetiology as meningioma [2-4] were also found to be responsive to the growth-inhibitory action of IFN- $\alpha$. Patients suffering from neurofibromatosis type 2 usually have multiple meningiomas, in addition to the characteristic bilateral acoustic ncurinomas; usually some of these meningiomas are inoperable. Possibly treatment with IFN$\alpha$ is beneficial in particular to these patients and to patients with inoperable meningiomas in general.

The data presented in this paper suggest that IFN- $\alpha$ may be used successfully in the treatment of actively growing meningiomas that are difficult to reach by surgery or that cannot be removed completely. Dosages and routes of administration are matters to be investigated. However, the effects in this study, which were observed at low dosages, are promising. Since meningiomas are located outside the blood brain barrier, no problems are to be expected in getting the drug to the desired place.

1. Kepes JJ. The histopathology of meningiomas. A reflection of origins and expected behaviour. 7 Neuropathol Exp Neurol 1986, 45, 95-107.

2. Seizinger BR, de la Monte S, Atkins L, Gusella JF, Martuza RL. Molecular genetic approach to human meningioma: loss of genes on chromosome 22. Proc Natl Acad Sci USA 1987, 84, 5419-5423.

3. Martuza RL, Seizinger BR, Jacoby LB, Rouleau A, Gusella JF. The molecular biology of human glial tumors. Trends Neurosci 1988, 11, 22-27.

4. Seizinger BR, Martuza RL, Gusella JF. Loss of genes on chromosome 22 in tumorigenesis of human acoustic neuroma. Nature 1986, 322, 644-647.

5. Marks SM, Whitwell HL, Lye RH. Recurrence of meningiomas after operation. Surg Neurol 1986, 25, 436-440.

6. Blankenstein MA, Blaauw G, Lamberts SWJ, Mulder E. Presence of progesterone receptors and absence of oestrogen receptors in human intracranial meningioma cytosols. Eur 7 Cancer Clin Oncol $1983,19,365-370$.

7. Waelti ER, Markwalder TM. Endocrine manipulation of meningiomas with medroxyprogesterone acetate. Effect of MPA on growth of primary meningioma cells in monolayer tissue culture. Surg Neurnl 1989, 31, 96-100.

8. Maiuri F, Montagnani S, Gallicchio B, Carandente M, Lanza GG, D'Andrea F. Oestrogen and progesterone sensitivity in cultured neningiunla cells. Neurvl Res 1989, 11, 9-13.

9. Koper JW, Foekens JA, Braakman R, Lamberts SWJ. Effects of progesterone on the response to epidermal growth factor and other growth factors in cultured human meningioma cells. Cancer Res $1990,50,2604-2607$

10. Reubi JC, Maurer R, Klijn JGM, et al. High incidence of somatostatin receptors in human meningiomas: biochemical characterization. 7 Clin Endocrinol Metab 1986, 63, 433-438.

11. Kunert-Radek J, Stepien H, Radek A, Pawlikowski M. Somatostatin suppression of meningioma cell proliferation in vitro. Acta Neurol Scand 1987, 75, 434-436.

12. Reubi JC, Horisberger U, Lang W, Koper JW, Braakman R, Lamberts SWJ. Coincidence of EGF receptors and somatostatin receptors in meningiomas but inverse, differentiaton-dependent relationship in glial tumors. Am f Pathol 1989, 134, 337-344.

13. Bergström $M$, Muhr C, Lundberg PO, et al. Modulation of tumor metabolism using hormonally acting drugs in patients with meningioma. F Endocrinol Invest 1989, 12 (Suppl. 2), 91.

14. Baron S, Dianzani F, Stanton GI, Fleischmann WR Ir, eds. The Interferon System. A Current Review to 1987. Austin, University of Texas Press, 1987.

15. Clemens MJ, NcNurlan MA. Regulation of cell proliferation and differentiation by interferons. Biochem $\mathcal{F} 1985,226,345-360$.

16. Friedman RM, Merigan T, Sreevalsan T, eds. Interferons as Cell Growth Inhibitors and Antitumor Factors. New York, Alan R. Liss, 1986.

17. Strander H. Clinical evaluation of treatment with interferon. Med Oncol Tumor Pharmacol 1989, 6, 87-91.

18. Hagemeijer A, Smit EME, Bootsma D. Improved identification of chromosomes of leukemic cells in methotrexatc trcated cultures. Cytogenet Cell Genet 1979, 23, 208-212

19. Trent J, Crickard K, Gibas Z, et al. Methodologic advances in the cytogenetic analysis of human solid tumors. Cancer Genet Cytogenet $1986,19,57-66$.

20. ISCN: Harnden DE, Klinger HP, eds. An International System for Human Cytogenetic Nomenclature. Basel, Karger, 1985. Published in collaboration with Cytogenet Cell Genet.

21. Downs TR, Wilfinger WW. Fluorimetric quantification of DNA in cells and tissue. Anal Biochem 1983, 131, 538-547.

22. Fickel G. Acoustic Neuroma Association Annual Meeting: NF-2 update. Neurofibromalosis $1989,2,57-66$

Acknowledgement-This research was supported by the Dutch Cancer Society. 